\title{
IMPACT OF VERBAL AND NON-VERBAL COMMUNICATION ON MARITAL STABILITY OF COUPLES IN UKUM LOCAL GOVERNMENT AREA OF BENUE STATE: COUNSELLING INTERVENTION.
}

\section{AKUME, GABRIEL TERZUNGWE Ph.D. AND SAATAN, RUTH MOVIHINZE}

\begin{abstract}
This study investigated the impact of verbal and non-verbal communication on marital stability of couples in Ukum Local Government Area of Benue State. The variables in this study examined were verbal and non-verbal communication. Two research questions and two hypotheses (at 0.5 level of significance) were formulated to guide the study. The survey design was adopted using 384 respondents randomly selected from a population of 70,360 married couples in the study area. A self structured, Marital Communication and Stability Inventory (MCSI) was used as an instrument to collect data for the study. The data obtained was analyzed using frequencies, percentages and chi-square statistics. It was found that, verbal and non verbal communication have significant impact on marital stability of couples in the area of study. The study therefore recommended among others that couples should learn to adopt effective marital communication in marriage relationship for peaceful coexistence. Counsellors should start early by organizing social clubs in primary and post primary schools to help students learn rudiments of interpersonal communication skills.
\end{abstract}

\section{Introduction}

In marriage relationship, one of the ways of ensuring a healthy and stable relationship is through marital communication. Marital communication ensures conflict resolution among married couples. Akinboye (1982), described it as the key to family interaction and successful relationship. The issue of communication in marriage cannot be overlooked. Filani (1985) reported that communication among couples is an important source of marital stability. The issue of separation among couples is no longer news in our ears due to poor communication between spouses. Couples that exhibit poor communication are prone to marital instability. Esere (2007) described communication as the life wire of marriage relationship. This means, as long as the couples are talking with each other, there is the chance that they will resolve the issues between them.

Interpersonal communication involves not only spoken words, but also body language, personal mannerism and style. It is a pillar which maintains the structure of personal co-existence and mutual understandings (Adeyemi \& Esere, 2007). Both verbal and nonverbal communication create meaning in a given context. Verbal talk, touching or body contact as indices in interpersonal communication remains very effective. Other examples include handshake, a pat at the back, raising of eye-brow, meaningful look, winking, gestures, 
nodding, shaking of head, frowning, smiling, yawning, hugging, beckoning, gazing and the like ar: usually very open in expression of thoughts and feelings nonverbally among couples in interpersonal relationship. Osamuyimen (1992) investigated the relationship between marital adjustment and marital affection, her findings indicate a significant relationship between communication and marital disaffection. It has been observed in Ukum Local Government Area of Benue State, that not much work has been done on the impact of marital communication on marital stability of couples, in the area, lack of effective marital communications seems to be a cause of marital instability and also a technique in resolving it. In the light of these, there is a missing link on impact of marital communication on marital stability of couples, which becomes the researchers point of concern.

\section{Statement of the Problem}

Marital instability and domestic violence are now common scenarios in many Nigerian homes, especially in the area under study. No wonder Sotonade (1999) observed that the current trend in marital relationship in Nigeria makes one to fear and doubt if any joy is really attached to marriage, or the thought of getting married. This is because most couples frequently disagree, quarrel, nag or fight with each other. The society's way of resolving such conflicts in law courts, social welfare offices, religious centres and traditional settings have often failed to produce desired results. Those who go to law courts go to obtain legal backings for separation and divorce, not for crises resolution. While most Nigerian spouses lack good communication skills, others simply do not see the need for discussing issues with a spouse (Nwobi, 1997). There are spouses who do not have time to listen to each other. Others feel that communication is only effective if it is verbal. In many homes careless utterances and negative communication patterns and skills are often in vogue. Thus trivial misunderstandings are allowed to escalate into big problems. The aforementioned literature have identified communication only as a causal factor in marital conflicts and a positive factor in marital adjustment and affection. Couples ought to know that accumulation and undisclosed grievances, if not talked over lead to resentments, bitterness, frustrations and tensions that give rise to instability at the slightest provocation.

The problem is that most couples in the area under study do not appreciate the potential impact marital communication could play in marriage instability or during crises periods. In this study, the researcher is out to find out the impact of marital communication on marital stability of couples in Ukum Local Government Area of Benue State.

\section{Purpose of the Study}

The purpose of this study is to determine the impact of marital communication on marital stability of couples in Ukum local government area of Benue State. The specific objectives includes.

1. To determine the impact of verbal communication on marital stability of couple in Ukum local government area.

2. To determine the impact of nonverbal communication on marital 
stability of couples in Ukum local government area.

\section{Research Questions}

The following questions guided the study:

1. What impact has verbal communication on marital stability among couples in Ukum local government area?

2. How does non-verbal communication impact on marital stability among couples in Ukum local government area?

\section{Research Hypotheses}

1. Verbal communication has no significant impact on marital stability of couples in Ukum local government area.

2. Non- verbal communication has no significant impact on marital stability of couples in Ukum local government area.

\section{Scope of the Study}

The study investigated the impact of marital communication on marital stability of couples in Ukum local government area. In terms of content, it is limited to the key variables of verbal and non-verbal communication in marriage.

\section{Research Procedure}

The survey design was used for this study. The area of study comprises Ukum Local Government Area of Benue State. The population for the study consists of married men and women in Ukum Local Government Area of Benue
State with population of 70,360 from the 13 councils/wards, according to the (NPC 2006). A sample size of 384 was arrived at following specification of Krejcie and Morgan (1970) recommendation for determining sample size of a given population.

Also the researchers used (Nigazis, 1984) proportional random sampling formular to select 384 respondents from the six wards in the local government areas to ensure a fair distribution of male and female in the area of study.

\section{Instrumentation}

The researchers designed a self constructed, four point likert type instrument called, Marital Communication and Stability Inventory (MCSI) used for data collection that addressed the research questions and hypotheses. The instrument comprised of section A-C. Section A sought information on Bio-data of the respondents. Section B sought information on the impact of verbal talk. Section $C$ elicited information on nonverbal talk. In scoring, the items were weighted from four for strongly Agree to one (4-1) for strongly disagree. The instrument was validated by subjecting it to the scrutiny of three experts in Research Method and Statistics at the Benue State University. Its reliability was ascertained through a pilot study which involved 50 respondents who were part of the population for the study but, were not in the study sample. The instrument was administered on them and their responses correlated, using split half method; for the purpose to determine the reliability of the instrument; The Spearman rank order correlation was used because of its 
internal consistenzies yielded a correlation coeffi ient of 0.88 considered reliable enough for this study. The two hypotheses were tested using chi-square statistics at .05 level of significance.

\section{Data Analyses and Results}

The researcher made use of descriptive statistics, frequencies and percentages for data analysis. Means statistics were used to answer the research questions, while chi-square goodness of fit was used to test the hypotheses at .05 level of significance. 384 questionnaires were distributed, properly completed and returned which were used in analyzing data for the study.

Table 1: Distribution of Respondents by Sex

\begin{tabular}{lllll}
\hline & Frequency & Percentage & Valid \% & Cumulative $\%$ \\
\hline Male & 196 & 51.0 & 51.0 & 51.0 \\
Female & 188 & 49.0 & 49.0 & 100 \\
\hline Total & $\mathbf{3 8 4}$ & $\mathbf{1 0 0 . 0}$ & $\mathbf{1 0 0 . 0}$ & $\mathbf{1 0 0 . 0}$ \\
\hline
\end{tabular}

Table 1 indicates that out of 384 respondents in this study, 196 or $51 \%$ were male, while 188 or $49 \%$ were female respondents.

\section{Research Question 1:}

What impact has verbal communication on marital stability among couples?

Table 2: Mean Score and Standard Deviation of Impact of verbal Communication on Marital Stability

\begin{tabular}{|c|c|c|c|}
\hline Responses & $\mathrm{N}$ & Mean & Std Dev. \\
\hline $\begin{array}{l}\text { Verbal talk gives information in our marriage and } \\
\text { prevents misunderstanding. }\end{array}$ & 384 & 3.17 & 0.56 \\
\hline $\begin{array}{l}\text { Verbal talk helps us as express opinion in our marriage } \\
\text { and improves our relationship. }\end{array}$ & 384 & 3.66 & 0.61 \\
\hline $\begin{array}{l}\text { Verbal talk gives room for growth of intimacy in our } \\
\text { marriage and stabilizes our marriage, }\end{array}$ & 384 & 3.46 & 0.68 \\
\hline $\begin{array}{l}\text { Verbal talk clarifies roles in marriage relationship and } \\
\text { complements each other. }\end{array}$ & 384 & 3.42 & 0.64 \\
\hline $\begin{array}{l}\text { Verbal talk creates room for dialogue in marriage and } \\
\text { helps us to understand each other. }\end{array}$ & 384 & 3.52 & 0.65 \\
\hline
\end{tabular}

Table 2, shows the respondents opinions on the impact of verbal communication on marital stability. The statement that verbal talk gives information and prevents misunderstanding in marriage yielded a score of 3.17. Similarly, the statement that verbal talk helps to express our opinion and improves relationship yielded 3.66, and the item which states that verbal talk creates room for dialogue in marriage and helps us to understand each other yielded 3.46. Verbal talk clarifies roles in marriage relationship and complements each other yielded 3.42. While the item, verbal talk creates room for dialogue in marriage 
and stabilizes our marriage yielded a mean score of 3.52. This implies that verbal talk has an impact on marital stability, since all the responses to the items yielded a mean response of more than 2.5 and above.

\section{Research Question 2:}

How does non-verbal communication impact on marital stability of couples?

Table 3: Mean Scores and Standard Deviation of impacts of Non-verbal Communication on marital Stability.

\begin{tabular}{|c|c|c|c|}
\hline Responses & $\mathrm{N}$ & Mean & $\begin{array}{l}\text { Std } \\
\text { Dev. }\end{array}$ \\
\hline $\begin{array}{l}\text { My spouse easily notices my facial expression and adjusts } \\
\text { quickly. }\end{array}$ & 384 & 2.58 & .86 \\
\hline $\begin{array}{l}\text { My spouse often admires my dress code and commends it, } \\
\text { this gives us satisfaction. }\end{array}$ & 384 & 3.7 & .43 \\
\hline My spouse's presence keeps me happy and contended & 384 & 3.20 & .82 \\
\hline $\begin{array}{l}\text { My spouse always hugs me each time I am back from work } \\
\text { and this makes me happy }\end{array}$ & 384 & 313 & .72 \\
\hline $\begin{array}{l}\text { Kissing between us usually expresses satisfaction and keeps } \\
\text { us happy }\end{array}$ & 384 & 2.38 & .86 \\
\hline
\end{tabular}

In our culture, kissing is not publicly considered accepted way of expressing love. This is probably the reason for the lower score. This implies that non-verbal communication has impact on marital stability.
Test of Hypotheses: Here chi-square statistics was used to test the following hypotheses at 0.05 level of significance.

Hypothesis I: Verbal communication has no significant impact on marital stability of couples.

Table 4: Impact of Verbal Communication on Marital Stability

\begin{tabular}{lllllll}
\hline & Observe & Expected & df & $X^{2}$ Cal & $X^{2}$-Crit & Sig at 0.05 \\
\hline Agree & 327 & 192 & & 189.84 & 3.84 & Sig \\
Disagree & 57 & 192 & 1 & & & \\
\hline
\end{tabular}

$$
\mathrm{X}^{2} \mathrm{Ca} 1=189.4, \mathrm{df}=1, \mathrm{P}<0.05
$$

Table 4 shows that the chi-square calculated value of 189.84 at df- 1 with crit. Value of 3.84 is significant. Therefore, the null hypothesis is rejected in favour of the alternate one which means, verbal communication has significant impact on marital stability.

Hypothesis 2: Non-verbal communication has no significant impact on marital stability of couples. 
Table 5: Impact of non-verbal communication on marital stability.

\begin{tabular}{lllllll}
\hline & Observe & Expected & df & $X^{2}$ Cal & $X^{2}$-Crit & Sig at 0.05 \\
\hline Agree & 264 & 192 & & 54.00 & 3.84 & Sig \\
Disagree & 120 & 192 & 1 & & & \\
\hline$X^{2}$-Cal $=54, \mathrm{df}=1, \mathrm{P}<0.05$
\end{tabular}

Table 10 shows that chi-square cal. value of 54.00 at $\mathrm{df}-1$ with crit. Value of 3.84 above the acceptable level of 0.05 was significant. This indicates that nonverbal communication has significant impact on marital stability.

\section{Discussion of Findings}

In the first null hypothesis, which says, there is no significant difference in impact of verbal communication on marital stability of couples, it was found that verbal communication has significant impact on marital stability of couples. This is in consonance with Woods and Cutts (1999) and Dumlua (2004) who maintained that, verbal communication helps spouses get information from one another. This helps couples resolve issues during instability. This is possible because during instability, priorities are misplaced, and goals are clouded. It is only through effective communication that couples could get their priorities right and clarify their goals, (Wikipedia 2007).

The second hypothesis revealed that non-verbal communication impacts positively on marital stability of couples. This agrees with the studies of Stanley and Markman (1997) and Smalley (2001) that : through non-verbal communication, couples convey their feelings of respect to one another. Conveyance of respect could be through speech or in nonverbal form. For instance, the wife may knee down to apologise to the husband. This singular action conveys a sign of respect for the husband, which will go a long way in healing the wounds of disrespect which the aggrieved husband might have been nursing. The researcher is in agreement that kind look, eye contact, tender touches can express wealth of love, that will keep the relationship stable and smooth. In contrast, unkind look, aggressive action from the partner, where present can put off the other partner.

\section{Conclusion}

Marital communication has been established as a very important factor towards marital stability, couples who want to enjoy stable marriage should be mindful and skilful in their verbal and non-verbal communication with one another.

\section{Counselling Intervention}

Counselling is particularly useful in helping people to understand themselves and their environment so as to be able to positively understand their motives and their environment for peaceful coexistence. Since verbal communication is found to impact positively on marriage stability, counsellors should embark on group and community based counselling in villages, using age grades, or peer groups, in churches, mosques and individuals to mention just a few, teaching couples what effective communication can do in marital 
stability. They can do this during premarital or marital counselling sessions as well as during PTA meetings. Counsellors should organize counselling clubs in secondary schools to start early with the younger ones in schools.

\section{References}

Akinboye, J.O. (1982). How to be happy in marriage. Psychology for every day living 11 (1) 65-74

Dumlo, R. (2004) Family communication Scholarship Current work and developing research frontier. California.

Esere, R. (2007). Getting to the negotiating agreement without giving in. Boston: Houghton Mlffrmn company.

Filani, T.O (1985). An experimental study of communication skill training and cognitive restructuring on the marital adjustment of some Nigerian couples. Ibadan: Nigeria publishing company.

Markman, H.J. (1991) Prediction of marital distress a 5 year follow up, Journal of marital counselling, 49 (5): 760-762.
Ngazi, G. (1984). Essentials of research methodology for Nigeria Educators. Ibadan: University Press.

Nwobi, C. (1997), Marriage and family counselling. Enugu: Pan African Publishers.

Osamuyimen, E. (1992). Relationship between marital adjustment communication, and marital dissatisfaction. Unpublished M.A Thesis, Ibadan.

Smalley, G. (2004). Marital conflict without casualties. New York: Penguim, Putman Inco.

Sotonade, A. 0 (1999). Family stability as a factor in reconstruction and transformation of a relation. The counsellor, 17 (1): 105-110.

Wikipedia, (2009). Verbal \& non-verbal communication Retrieved on January 6, 2009 from http://en.uiikipedia.

org/wikiveral/non-verbal communication.

Woods, AM \& Cutts L. (1999). Communication NC Fasser, Inter-disciplinary curriculum resource document. New York: University Press. 